\title{
Nitrous oxide emissions with enhanced efficiency and conventional urea fertilizers in winter wheat
}

\author{
Haibo An · Jen Owens $\mathbb{C} \cdot$ Brian Beres $\cdot$ Yuejin Li $\cdot$ Xiying Hao
}

Received: 14 January 2020/Accepted: 9 January 2021 / Published online: 13 February 2021

(C) Crown 2021

\begin{abstract}
Optimizing nitrogen fertilizer management can reduce nitrous oxide $\left(\mathrm{N}_{2} \mathrm{O}\right)$ emissions. This study tested if split applying enhanced efficiency fertilizers (EEFs) resulted in lower $\mathrm{N}_{2} \mathrm{O}$ emissions than applying equivalent rates of urea at planting. In semiarid southern Alberta, field trials were conducted during three years (planting to harvest) in rainfed winter wheat crops. Annual fertilizer rates ranged from 146 to $176 \mathrm{~kg} \mathrm{~N} \mathrm{ha}^{-1}$. Fertilizer types were urea, and three EEFs (polymer-coated urea, urea with urease and nitrification inhibitors, and urea with a nitrification inhibitor). Each fertilizer type was applied three ways: $100 \%$ banded at planting, split applied $30 \%$ banded at planting and $70 \%$ broadcast in late fall, and split applied 30\% banded at planting and $70 \%$ broadcast at Feekes growth stage 4 (GS4, post-tiller formation, wheat entering the greening up phase in the early spring). Nitrous oxide was measured using static chambers between sub-weekly and monthly from
\end{abstract}

Supplementary Information The online version contains supplementary material available at https://doi.org/10.1007/ s10705-021-10118-9.

H. An · Y. Li

College of Grassland, Resources and Environment, Inner Mongolia Agriculture University, Inner Mongolia, China

H. An · J. Owens $(\square) \cdot$ B. Beres $\cdot$ X. Hao

Agriculture and Agri-Food Canada Lethbridge Research and Development Centre, Lethbridge,

$\mathrm{AB}$, Canada

e-mail: Jennifer.Owens@Canada.ca planting to harvest. Over three years, cumulative $\mathrm{N}_{2} \mathrm{O}$ emissions ranged from 0.16 to $1.32 \mathrm{~kg} \mathrm{~N} \mathrm{ha}^{-1}$. This was equivalent to emissions factors between 0.009 and $0.688 \%$. Cumulative $\mathrm{N}_{2} \mathrm{O}$ emissions and emissions factors did not differ between fertilizer types, but they were lower when fertilizer was split applied at GS4 compared to in late fall $(P \leq 0.10)$. Our study suggests that EEFs do not reduce $\mathrm{N}_{2} \mathrm{O}$ emissions from rainfed winter wheat crops, but a well-timed split application with a majority of fertilizer applied after winter can minimize $\mathrm{N}_{2} \mathrm{O}$ emissions.

Keywords Nitrogen fertilizer - Nitrification inhibitor · Polymer-coated urea $\cdot$ Urease inhibitor

\section{Introduction}

Optimizing nitrogen $(\mathrm{N})$ fertilization by aiming to match $\mathrm{N}$ supply from fertilizer with $\mathrm{N}$ crop demand can reduce excess available soil $\mathrm{N}$, and when this is achieved, soil $\mathrm{N}_{2} \mathrm{O}$ production may also be minimized. There are a few strategies that may help accomplish this. The first is substituting urea with enhanced efficiency fertilizers (EEFs). Enhanced efficiency fertilizers can prolong $\mathrm{N}$ as ammonium $\left(\mathrm{NH}_{4}{ }^{+}\right)$, which can help reduce nitrate $\left(\mathrm{NO}_{3}{ }^{-}\right)$accumulation in soil thereby preventing $\mathrm{N}$ transformations to gaseous $\mathrm{N}$ forms like $\mathrm{N}_{2} \mathrm{O}$ (Akiyama et al. 2010; Trenkel 2010). 
Types of EEFs include slow-release fertilizers that physically encapsulate urea allowing fertilizer to gradually diffuse into the soil, and fertilizers containing chemical urease inhibitors (UI) and nitrification inhibitors (NI) which slow the conversion of urea to $\mathrm{NH}_{4}{ }^{+}$, and $\mathrm{NH}_{4}{ }^{+}$to $\mathrm{NO}_{3}{ }^{-}$, respectively. A second strategy that may help optimize $\mathrm{N}$ fertilization is split applying fertilizer at different times throughout a crop cycle rather than applying once at planting. This strategy attempts to time fertilizer application with accelerated plant $\mathrm{N}$ demand. This can improve crop $\mathrm{N}$ use efficiency thereby minimizing available $\mathrm{N}$ accumulation in soil. Since neither split application nor EEFs directly inhibits $\mathrm{N}_{2} \mathrm{O}$ production, they are not universal prescriptions for mitigating fertilizer-induced $\mathrm{N}_{2} \mathrm{O}$ emissions.

Developing a fertilizer strategy will consider crop characteristics. For winter wheat, only $30 \%$ of it's total $\mathrm{N}$ is required before the tillering stage (Mahler et al. 1994). Split fertilizer application whereby a majority of $\mathrm{N}$ is applied in spring (April) prior to Zaddocks growth stage 24 has been shown to maximize yield and $\mathrm{N}$ use efficiency (Mahler et al. 1994). However, fertilizer split-applied at planting in the fall and early spring risks partly missing the window of accelerated crop $\mathrm{N}$ uptake after the tillering stage. This risk could be minimized by applying fertilizer in late fall, which would eliminate the need to properly time fertilizer application in the spring, but risks enhancing $\mathrm{N}_{2} \mathrm{O}$ emissions during late winter thaw events. A solution may be to split apply EEFs. Delaying $\mathrm{N}$ availability with EEFs may compensate for an ill-timed fertilizer application in cases where the timing of fertilization is not synchronized with crop $\mathrm{N}$ demand.

How coupling EEFs and split application affects fertilizer-induced $\mathrm{N}_{2} \mathrm{O}$ emissions in semiarid climates is difficult to predict, especially for winter crops. Natural variation in precipitation in these climates makes it challenging to anticipate which soil conditions will coincide with high $\mathrm{N}$ availability from fertilizer. The timing and amount of rainfall following $\mathrm{N}$ fertilizer application affects urea hydrolysis (Black et al. 1985, 1987) and $\mathrm{N}_{2} \mathrm{O}$ production (Austin et al. 2004). Therefore, applying $\mathrm{N}$ fertilizer to dry soil does not necessarily lead to increases in $\mathrm{N}_{2} \mathrm{O}$ emissions (Barton et al. 2008), and relatively low cumulative $\mathrm{N}_{2} \mathrm{O}$ emissions and emissions factors are expected from fertilized soils in dry climates (Hergoualc' $h$ et al. 2019).
The objectives of this study were to test whether different combinations of EEFs and split application reduced $\mathrm{N}_{2} \mathrm{O}$ emissions and emissions factors compared with urea applied $100 \%$ at planting in a rainfed, semiarid winter wheat crop. We hypothesized that applying all fertilizer in the fall will increase $\mathrm{N}_{2} \mathrm{O}$ emission but a split application of EEFs at planting and in the spring will minimize $\mathrm{N}_{2} \mathrm{O}$ emissions and emissions factors.

\section{Materials and methods}

Site description and management

This study was conducted in Lethbridge, Alberta, Canada. The mean annual precipitation is $370.2 \mathrm{~mm}$, mean annual air temperature is $5.5^{\circ} \mathrm{C}(1988-2017)$, and the elevation is $910 \mathrm{~m}$.

Three trials took place from 2014 to 2017, each trial starting in September and ending in July of the following year. The trials were conducted on different fields each year: "Year 1" (2014-2015) at 49 34' $03.6^{\prime \prime} \mathrm{N}, 112^{\circ} 44^{\prime} 02.0^{\prime \prime} \mathrm{W}$; "Year 2" (2015-2016) at $49^{\circ} 40^{\prime} 49.7^{\prime \prime} \mathrm{N}, 112^{\circ} 27^{\prime} 24.3^{\prime \prime} \mathrm{W}$; and "Year 3" (2016-2017) at $49^{\circ} 40^{\prime} 48.5^{\prime \prime} \mathrm{N}, 112^{\circ} 45^{\prime} 39.5^{\prime \prime} \mathrm{W}$. All sites were located within $20 \mathrm{~km}$ of each other (Supplementary Figure S1). The soil is an Orthic Dark Brown Chernozem (Typic Haploborall). Soil had a heavy clay texture in Year 1 and a clay soil texture in Years 2 and 3 (Soil Classification Working Group 1998). Soil chemical and physical properties for each soil are shown in Table 1. Methods used to determine the initial soil properties are detailed in the Supplementary Data.

\section{Crop details}

A rotation of canola and barley was cultivated for at least four years prior to the start of the trials, and fertilized with $39 \mathrm{~kg} \mathrm{ha}^{-1}$ of 34-17-0 urea-ammonium-phosphate. Winter wheat (Triticum aestivum, AC Flourish, a Canada Western Red Winter milling quality variety) was seeded in the fall into standing canola (Brassica spp.) using a SeedHawk seeder (Vaderstad Industries Inc., Langbank, Saskatchewan, Canada). 
Table 1 Means ( \pm standard error of the mean) of soil properties across the study years, determined before first fertilizer application

\begin{tabular}{|c|c|c|c|}
\hline Variable & Year 1 (2014-2015) & Year 2 (2015-2016) & Year 3 (2016-2017) \\
\hline \multicolumn{4}{|l|}{ Soil } \\
\hline $\mathrm{pH}$ & $8.29(0.07)$ & $6.71(0.12)$ & $7.08(0.35)$ \\
\hline Electrical conductivity $\left(\mathrm{dS} \mathrm{m}^{-1}\right)$ & $0.24(0.07)$ & $0.16(0.02)$ & $0.13(0.02)$ \\
\hline Water-extractable organic carbon $\left(\mathrm{mg} \mathrm{C} \mathrm{kg}^{-1}\right)$ & $64.10(2.71)$ & $49.41(5.79)$ & $54.60(1.63)$ \\
\hline Nitrate $\left(\mathrm{mg} \mathrm{N} \mathrm{kg}^{-1}\right)$ & $3.35(0.45)$ & $13.59(1.66)$ & $2.91(0.18)$ \\
\hline Ammonium ( $\mathrm{mg} \mathrm{N} \mathrm{kg}^{-1}$ ) & $2.30(0.38)$ & $3.48(1.31)$ & $2.91(0.59)$ \\
\hline Total carbon $\left(\mathrm{g} \mathrm{kg}^{-1}\right)$ & $17.04(0.36)$ & $14.60(0.47)$ & $12.72(0.58)$ \\
\hline Total nitrogen $\left(\mathrm{g} \mathrm{kg}^{-1}\right)$ & $1.81(0.03)$ & $1.50(0.03)$ & $1.44(0.05)$ \\
\hline $\mathrm{C} / \mathrm{N}$ ratio & $9.45(0.35)$ & $9.73(0.21)$ & $8.86(0.14)$ \\
\hline Bulk density $\left(\mathrm{g} \mathrm{cm}^{-3}\right)$ & $1.17(0.01)$ & $1.10(0.01)$ & $1.02(0.01)$ \\
\hline Clay $\left(\mathrm{g} \mathrm{kg}^{-1}\right)$ & $596(7)$ & $289(4)$ & $340(14)$ \\
\hline Sand $\left(\mathrm{g} \mathrm{kg}^{-1}\right)$ & $121(4)$ & $404(2)$ & $376(15)$ \\
\hline Silt $\left(\mathrm{g} \mathrm{kg}^{-1}\right)$ & $283(6)$ & $306(5)$ & $284(10)$ \\
\hline \multicolumn{4}{|l|}{ Climate } \\
\hline \multicolumn{4}{|l|}{ Temperature } \\
\hline Overall & 6.1 & 6.5 & 5.1 \\
\hline Autumn & 10.8 & 9.9 & 8.6 \\
\hline Winter & -1.0 & 0.2 & -3.7 \\
\hline Spring and summer & 13.7 & 13.8 & 13.5 \\
\hline \multicolumn{4}{|l|}{ WFPS $(\%)$} \\
\hline Overall & 48.2 & 37.4 & 38.7 \\
\hline Autumn & 37.3 & 31.0 & 34.5 \\
\hline Winter & 56.3 & 39.3 & 40.4 \\
\hline Spring and summer & 40.9 & 36.6 & 38.4 \\
\hline \multicolumn{4}{|l|}{ Precipitation (mm) } \\
\hline Overall & 235.5 & 270.5 & 261.5 \\
\hline Autumn & 20.5 & 7.6 & 50.8 \\
\hline Winter & 94.5 & 83.3 & 68.8 \\
\hline Spring and summer & 120.5 & 179.6 & 141.9 \\
\hline
\end{tabular}

Mean air temperature, soil water-filled pore space (WFPS) at $50 \mathrm{~mm}$, and total precipitation for each year, presented over the course of the entire sampling time and by season (autumn = September-October inclusive, winter = November-March inclusive, and spring and summer $=$ April-July inclusive) temperature and precipitation from the Lethbridge weather station

\section{Determining fertilizer rates}

Soil N supply was estimated each year before the first fertilizer application using plant root simulator (PRS) probes (Western Ag Innovations, Saskatoon, SK, Canada). These synthetic ion exchange resins strips were buried in the soil and mimic the properties of root exchange to determine soil nutrient availability. These data were used to forecast $\mathrm{N}$ fertilizer requirements with the PRS ${ }^{\mathrm{TM}}$ Nutrient Forecaster model (Hangs et al. 2002).
Enhanced efficiency fertilizers may improve $\mathrm{N}$ use efficiency, but they are more expensive than conventional fertilizers. Cereal crop $\mathrm{N}$ use is generally $<50 \%$ of fertilizer applied (Raun and Johnson 1999). Applying higher rates of $\mathrm{N}$ as fertilizer may maximize yield but may not provide the greatest profit per area. Therefore, the fertilizers were applied at $80 \%$ of the target rate, targeting a $5380 \mathrm{~kg} \mathrm{ha}^{-1}$ (80 bu $\mathrm{ac}^{-1}$ ) crop. 
Experimental design

Treatments (three applications, four fertilizer types) were arranged in a complete block design with three blocks. Each block also contained one non-fertilized treatment (control) for a total of 39 plots. Plots were $3.7 \mathrm{~m}$ wide $\times 15.2 \mathrm{~m}$ long, with $1 \mathrm{~m}$ buffers. Each block measured $60.1 \mathrm{~m} \times 15.2 \mathrm{~m}$.

Each fertilizer type was applied with each of the following timings and placements: (1) $100 \%$ of $\mathrm{N}$ banded in the fall at planting (hereafter referred to as "planting"); (2) $30 \%$ banded in the fall at planting and $70 \%$ broadcast in late fall (hereafter referred to as "late fall"); and (3) 30\% banded in the fall at planting and $70 \%$ broadcast at Feekes growth stage 4 (GS4, post-tiller formation, wheat entering the greening up phase in the early spring, hereafter referred to as "GS4") (Large 1954). Fertilizer applied at seeding was side-banded and at other times was surface broadcast unincorporated in-crop.

The four fertilizer types were: (1) urea $(46 \% \mathrm{~N}$ $\mathrm{w} / \mathrm{w})$; (2) polymer-coated urea (hereafter referred to as "PCU"; ESN® Environmentally Smart Nitrogen, Nutrien, Saskatoon, SK, Canada; 44\% N w/w); (3) SuperU (hereafter referred to as "NI + UI"; Koch Agronomic Services, Wichita, KS, USA; 46\% N w/w) which is urea with the nitrification inhibitor dicyandiamide (DCD) and urease inhibitor N-(n-butyl) thiophosphoric triamide (NBPT); and (4) urea impregnated with Instinct (hereafter referred to as "NI"), the nitrification inhibitor nitrapyrin (Dow AgroSciences, Indianapolis, IN, USA; $46 \% \mathrm{~N} \mathrm{w/w).}$

The total fertilizer application rates and dates of fertilizer application for each year are presented in Table 2.
Ancillary environmental variables

Daily total precipitation ( $\mathrm{mm})$, mean volumetric soil moisture (\%, measured at $50 \mathrm{~mm}$ soil depth), and mean air temperature $\left({ }^{\circ} \mathrm{C}\right)$ were monitored for the duration of the experiment at a nearby weather station (within $15 \mathrm{~km}$ of each site, $49.68^{\circ} \mathrm{N}, 112.75^{\circ} \mathrm{W}$, $991 \mathrm{~m}$ elevation).

Soil bulk density from each field was determined by taking at least three randomly situated intact soil cores (height $=150 \mathrm{~mm}$, inner diameter $=65 \mathrm{~mm}$ ) and oven drying at $105{ }^{\circ} \mathrm{C}$ for $72 \mathrm{~h}$. Soil water-filled pore space (WFPS, \%) at $50 \mathrm{~mm}$ soil depth was calculated using the volumetric water content measured from the weather station and the average soil bulk density (Linn and Doran 1984).

\section{$\mathrm{N}_{2} \mathrm{O}$ sampling and analysis}

Soil-to-atmosphere $\mathrm{N}_{2} \mathrm{O}$ fluxes were measured using vented static chambers $(300 \mathrm{~mm}$ inner diameter, $100 \mathrm{~mm}$ height, one chamber per plot) with a PVC base collar installed to a depth of $50 \mathrm{~mm}$ (Chang et al. 1998). Samples were collected between 8:00 am and 12:00 pm local time. Wheat inside the collars was clipped regularly. Gas samples $(11.3 \mathrm{~mL})$ were extracted from the chamber headspace using a syringe at $0,15,30$, and $60 \mathrm{~min}$ after securing the chamber lid to the collar. Gas samples were immediately transferred to an evacuated vial $\left(5.8 \mathrm{~mL}\right.$, Exetainer ${ }^{\circledR}$, Labco Ltd., Lampeter, United Kingdom) and analyzed using a Varian 3800 gas chromatograph equipped with an electron capture detector (Varian Inc., Walnut Creek, CA, USA). The injector and column temperatures were kept at $55^{\circ} \mathrm{C}$. The carrier was $\mathrm{P} 10$ gas (10\% methane, balance argon). The channel was maintained at a static pressure of $150 \mathrm{kPa}$.

Table 2 The dates of fertilizer application at planting, late fall, and Feekes growth stage 4 (GS4), and rates of N application for each year

\begin{tabular}{|c|c|c|c|c|c|c|}
\hline \multirow[t]{2}{*}{ Year } & \multicolumn{3}{|l|}{ Date } & \multicolumn{3}{|c|}{ Application rate $\left(\mathrm{kg} \mathrm{N} \mathrm{ha}^{-1}\right)$} \\
\hline & Planting & Late fall & GS4 & $100 \%$ & $30 \%$ & $70 \%$ \\
\hline Year 1 & September 17, 2014 & November 19, 2014 & April 13, 2015 & 175 & 52.5 & 122.5 \\
\hline Year 2 & September 24, 2015 & November 17, 2015 & April 12, 2016 & 146 & 43.8 & 102.2 \\
\hline Year 3 & September 16, 2016 & November 15, 2016 & April 7, 2017 & 176 & 52.8 & 123.2 \\
\hline
\end{tabular}


Nitrous oxide fluxes $\left(\mathrm{g} \mathrm{N} \mathrm{ha}^{-1}\right.$ day $^{-1}$ ) were calculated using the slope of either a quadratic or linear regression of the $\mathrm{N}_{2} \mathrm{O}$ concentration over time $(1 \mathrm{~h})$, the ideal gas law (assuming standard atmospheric pressure adjusted for elevation of each site), air temperature (daily average), chamber area $\left(0.0707 \mathrm{~m}^{2}\right)$, and chamber volume $(\sim 7 \mathrm{~L}$, adjusted individually for each chamber using the internal radius of the chamber area and heights of the chamber walls above the surface which were measured at the start of the trial) (Venterea et al. 2012). All regressions were strong (e.g. $\mathrm{R}^{2}>0.80$ ) indicating no serious quality control issues. Quadratic regression was selected except when the $\mathrm{R}^{2}$ of the linear regression was higher. The minimum detectable fluxes (Parkin et al. 2012) were $\pm 1.9 \mu \mathrm{g} \mathrm{N} \mathrm{m}^{-2} \mathrm{~h}^{-1}$ for fluxes calculated using linear regression and $\pm 6.5 \mu \mathrm{g} \mathrm{N} \mathrm{m}^{-2}$ $\mathrm{h}^{-1}$ for fluxes calculated using quadratic regression. All fluxes were determined to be above the minimum detectable flux.

Nitrous oxide fluxes were measured approximately twice a week after planting for two months, weekly for a month after the late fall fertilizer application, and weekly for two months after the GS4 fertilizer application. Throughout the winter, the $\mathrm{N}_{2} \mathrm{O}$ fluxes were measured once or twice a month.

Winter $\mathrm{N}_{2} \mathrm{O}$ measurements were made following the same protocol as measurements at other times of the year. When snow was present in the chambers, the volume of the chamber occupied by snow was calculated. This was done using the radius of the internal chamber area and the height of the snow pack. This snow-filled volume was adjusted using a snow water equivalent value that was estimated using a jar to take snow samples and assuming the density of water is $1 \mathrm{~g} \mathrm{~cm}^{-3}$ (Sturm et al. 2010). The volume of the chamber occupied by snow, as represented by the snow water equivalent, was subtracted from the volume of the chamber without snow, and this adjusted headspace volume was used in the winter $\mathrm{N}_{2} \mathrm{O}$ flux calculations.

Nitrous oxide fluxes were measured a total of 31 , 30, and 29 times in Years 1, 2, and 3, respectively. Final $\mathrm{N}_{2} \mathrm{O}$ measurements were made on July 29, 2015, in Year 1, on July 21, 2016, in Year 2, and on July 19, 2017, in Year 3.

Winter wheat was harvested on July 30, 2015, in Year 1, July 29, 2016, in Year 2, and July 27, 2017, in Year 3. For the purposes of this study, the "winter wheat crop cycle" starts at planting and ends with the last $\mathrm{N}_{2} \mathrm{O}$ measurement, and was therefore 315 days for Year 1, 301 days for Year 2, and 306 days for Year 3.

Cumulative $\mathrm{N}_{2} \mathrm{O}$ emissions $\left(\mathrm{kg} \mathrm{N} \mathrm{ha}^{-1}\right)$ over the winter wheat crop cycle were calculated by linearly interpolating between sampling dates and summing the values.

\section{Emissions factors}

The $\mathrm{N}_{2} \mathrm{O}$ emissions factors $\left(\mathrm{N}_{2} \mathrm{O}-\mathrm{N}\right.$ emitted as a $\%$ of $\mathrm{N}$ applied as fertilizer) were calculated by subtracting the control treatment cumulative $\mathrm{N}_{2} \mathrm{O}$ emissions from each fertilized soil cumulative $\mathrm{N}_{2} \mathrm{O}$ emissions, dividing by the total $\mathrm{N}$ applied as fertilizer and multiplying by 100 (Gregorich et al. 2005).

\section{Soil ammonium and nitrate concentrations}

Soil samples were collected a total of 9, 13, and 11 times in Years 1, 2, and 3, respectively, using a hand auger. For the first month after planting, weekly soil samples $(0-150 \mathrm{~mm})$ were collected. Thereafter, monthly soil samples were collected, except during the winter in Years 1 and 3 when the soil was frozen. Fresh soils were extracted for $\mathrm{NO}_{3}{ }^{-}$and $\mathrm{NH}_{4}{ }^{+}$by $2 \mathrm{~mol} \mathrm{~L}^{-1} \mathrm{KCl}$ (Keeney and Nelson 1982) at a 1:5 (weight:volume) ratio of soil to solution, mixed for 30 min., and analyzed using a modified Indophenol Blue technique (Sims et al. 1995) with a MultiSkan Go Microplate Spectrophotometer at $650 \mathrm{~nm}$ (Thermo Scientific, Waltham, MA, USA). Gravimetric soil moisture was determined for each soil sample by oven-drying $\sim 10 \mathrm{~g}$ field moist soil at $105^{\circ} \mathrm{C}$ for $72 \mathrm{~h}$. The gravimetric water content was used to present soil $\mathrm{NH}_{4}{ }^{+}$and $\mathrm{NO}_{3}{ }^{-}$as $\mathrm{mg} \mathrm{N} \mathrm{kg}^{-1}$ dry weight of soil.

\section{Data presentation and statistical analysis}

Data were assessed for normality using the ShapiroWilk test and for homogeneity of variance using Levene's test (RStudio, version 3.4.4). None of the datasets were transformed.

Linear associations between daily $\mathrm{N}_{2} \mathrm{O}$ fluxes, WFPS, air temperature, soil $\mathrm{NH}_{4}{ }^{+}$, and soil $\mathrm{NO}_{3}{ }^{-}$ were evaluated for each combination of Year, fertilizer type, and fertilizer application using Pearson's correlation coefficient (r) at $P \leq 0.05$ using the 
corr.test base function in $\mathrm{R}$ Statistics. Because daily $\mathrm{N}_{2} \mathrm{O}$ fluxes were measured more frequently than soil $\mathrm{NH}_{4}{ }^{+}$and $\mathrm{NO}_{3}{ }^{-}$concentrations, linear interpolation was used to estimate $\mathrm{NH}_{4}{ }^{+}$and $\mathrm{NO}_{3}{ }^{-}$concentrations for association with daily $\mathrm{N}_{2} \mathrm{O}$ fluxes. Linear multiple regression models with daily $\mathrm{N}_{2} \mathrm{O}$ fluxes as the dependent variable, and WFPS, soil temperature, soil $\mathrm{NH}_{4}{ }^{+}$, and soil $\mathrm{NO}_{3}{ }^{-}$as potential independent predictors were evaluated for each combination of Year, fertilizer type, and fertilizer application using the $l m$ base function in R Statistics. Models for all combinations of one, two, three, or four of these predictors were evaluated and final models were selected based on the adjusted $\mathrm{R}^{2}$ and Akaike Information Criterion (Kutner et al. 2004).

A mixed-model ANOVA was conducted to determine if there were differences in cumulative $\mathrm{N}_{2} \mathrm{O}$ emissions and emissions factors between different fertilizer types, application, and Years. Block was treated as a random effect. Only cumulative $\mathrm{N}_{2} \mathrm{O}$ emissions from fertilized soils were statistically compared. Multiple comparisons of means were conducted using Tukey's HSD test using the agricolae package in R Statistics when main effects or their interactions were significant at a 0.05 probability level. Differences that may be biologically or chemically important were explored when the probability level was between 0.05 and 0.10 .

\section{Results}

Soil environmental conditions, and ammonium and nitrate concentrations

There were some differences in soil conditions between years. Soil $\mathrm{pH}$ and clay content were relatively higher in Year 1 compared to the other years (Table 1). The overall average WFPS was highest in Year $1(48.2 \%)$ and similar in Years 2 and 3 (37.4 and $38.7 \%$ ) (Table 1). Water-filled pore space increased following precipitation except during the winter, where WFPS increased during thaw events (Figs. 1, 2, 3b, c).

Considering all data, $\mathrm{NH}_{4}{ }^{+}$ranged from 0.05 to $81.70 \mathrm{mg} \mathrm{N} \mathrm{kg}^{-1}$ (Figs. 1, 2, 3d, g, j) and $\mathrm{NO}_{3}{ }^{-}$ ranged from 0.11 to $58.52 \mathrm{mg} \mathrm{N} \mathrm{kg}^{-1}$ (Figs. 1, 2, 3e, $\mathrm{h}, \mathrm{k})$.
In Year 1 and Year 2 for all applications, and Year 3 for $100 \%$ applied at planting, $\mathrm{NH}_{4}{ }^{+}$and $\mathrm{NO}_{3}{ }^{-}$ increased after fertilization at planting. There were no clear patterns in $\mathrm{NH}_{4}{ }^{+}$and $\mathrm{NO}_{3}{ }^{-}$when fertilizer was applied in late fall or at GS4.

Winter $\mathrm{NH}_{4}{ }^{+}$and $\mathrm{NO}_{3}{ }^{-}$were only measured during Year 2. During Year 2, from the start of December to the end of February, $\mathrm{NH}_{4}{ }^{+}$ranged from 1.83 to $51.43 \mathrm{mg} \mathrm{N} \mathrm{kg}^{-1}$ and $\mathrm{NO}_{3}{ }^{-}$ranged from 0.75 to $18.53 \mathrm{mg} \mathrm{N} \mathrm{kg}^{-1}$ from fertilized treatments. In the winter, $\mathrm{NH}_{4}{ }^{+}$concentrations tended to be higher in treatments where all fertilizer was applied in the fall (Fig. 2d, g).

Over all years, growing season (March 1 onwards) $\mathrm{NH}_{4}{ }^{+}$ranged from 0.06 to $39.71 \mathrm{mg} \mathrm{N} \mathrm{kg}^{-1}$ and $\mathrm{NO}_{3}{ }^{-}$ranged from 0.02 to $57.63 \mathrm{mg} \mathrm{N} \mathrm{kg}^{-1}$ from fertilized soils. In Year 2, $\mathrm{NO}_{3}{ }^{-}$increased in all treatments including the control following precipitation-induced increases in WFPS (Fig. 2e, h, k).

Nitrous oxide fluxes

In Year 1, small spikes in $\mathrm{N}_{2} \mathrm{O}$ fluxes followed fertilizer application, most notably when fertilizer was applied 100\% at planting (Fig. 1f). Urea applied 100\% at planting showed the highest average $\mathrm{N}_{2} \mathrm{O}$ fluxes within the month after application $\left(5.12 \mathrm{~g} \mathrm{~N} \mathrm{ha}^{-1}\right.$ $\mathrm{day}^{-1}$ ). In treatments where all fertilizer was applied $100 \%$ at planting or split applied in late fall, $\mathrm{N}_{2} \mathrm{O}$ fluxes of similar magnitudes were measured in the fall and winter (Fig. 1f, i). All fertilizer types and applications showed relatively low $\mathrm{N}_{2} \mathrm{O}$ fluxes during the spring and summer, even when fertilizer was applied at GS4; from March 1 onward, $\mathrm{N}_{2} \mathrm{O}$ fluxes were $\leq 3.55 \mathrm{~g} \mathrm{~N} \mathrm{ha}^{-1}$ day $^{-1}$ from all fertilized soils.

In Year 2, $\mathrm{N}_{2} \mathrm{O}$ fluxes tended to be relatively low after fertilizer application at planting, during the late fall fertilizer application, and during the winter. From planting until March 1, fluxes were $\leq 5.44 \mathrm{~g} \mathrm{~N} \mathrm{ha}^{-1}$ day $^{-1}$ from all fertilizer types and applications except Urea applied at GS4 (Fig. 2f, i, 1). Nitrous oxide fluxes showed greater variability from all fertilizer types and applications during the spring and summer when temperatures were warm and there was available soil $\mathrm{NO}_{3}{ }^{-}$; from March 1, 2016, onward, mean fluxes were $2.94 \mathrm{~g} \mathrm{~N} \mathrm{ha}^{-1} \mathrm{day}^{-1}$, ranging from 0.11 to $11.81 \mathrm{~g} \mathrm{~N} \mathrm{ha}^{-1}$ day $^{-1}$. Nitrous oxide fluxes from Urea applied at GS4 were notably higher throughout the trial (mean of 
Fig. 1 a Air temperature, b precipitation (rain + snow), c waterfilled pore space at $50 \mathrm{~mm}$, and mean ( \pm the standard error of the mean) soil ammonium, soil nitrate and nitrous oxide fluxes for fertilizer applied $100 \%$ at planting (d-f), 30\% applied at planting and $70 \%$ applied in late fall (g-i), and $30 \%$ applied at planting and $70 \%$ applied at Feekes growth stage $4(\mathbf{j}-\mathbf{l})$ for Year 1 (2014-2015). The black arrows represent the timing of fertilizer application
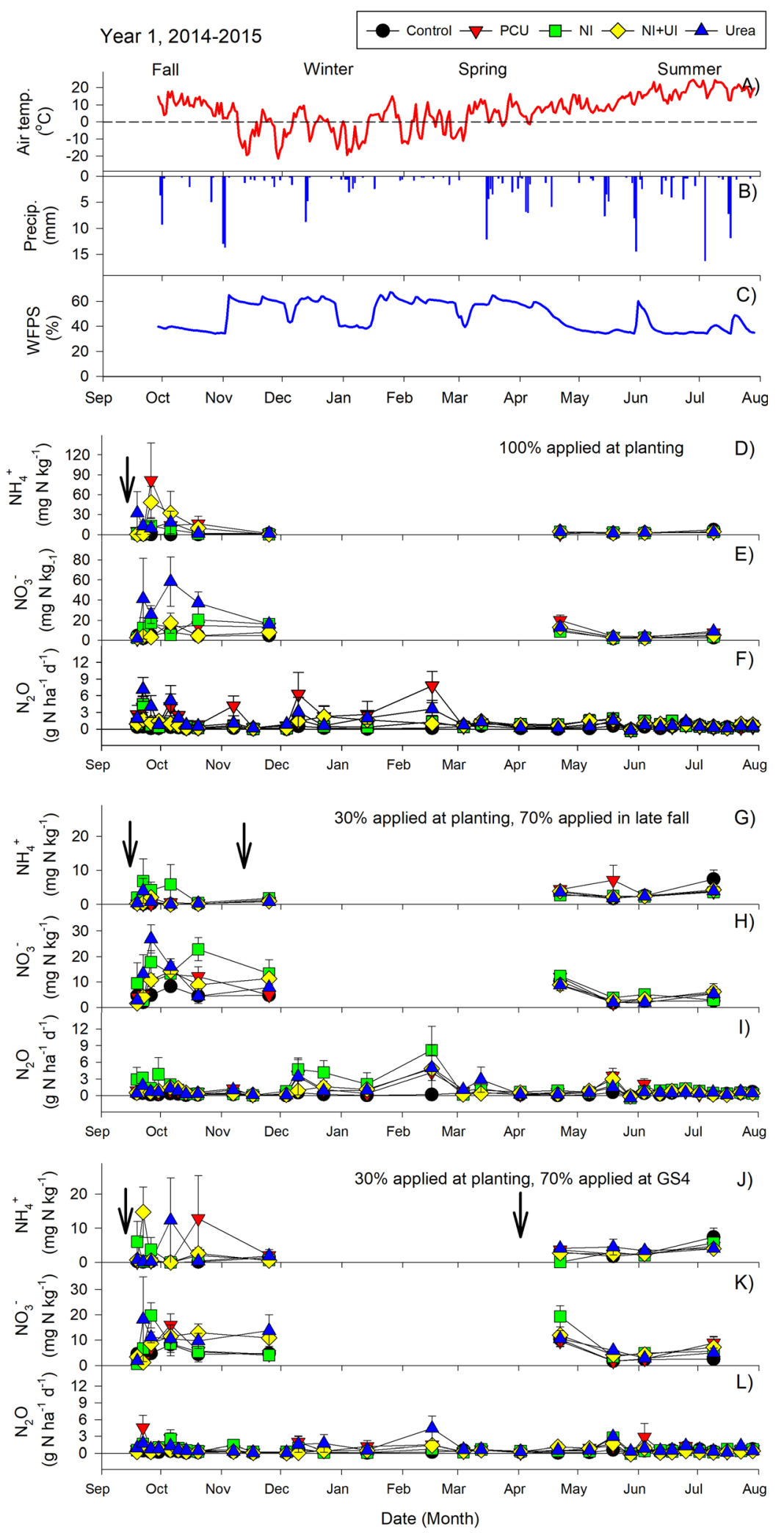
Fig. 2 a Air temperature, b precipitation (rain + snow), c waterfilled pore space at $50 \mathrm{~mm}$, and mean ( \pm the standard error of the mean) soil ammonium, soil nitrate and nitrous oxide fluxes for fluxes applied $100 \%$ at planting fertilizer $(\mathbf{d}-\mathbf{f})$, $30 \%$ applied at planting and $70 \%$ applied in late fall $(\mathbf{g}-$ i), and $30 \%$ applied at planting and $70 \%$ applied at Feekes growth stage $4(\mathbf{j}-$

l) for Year 2 (2015-2016). The black arrows represent the timing of fertilizer application
Year 2, 2015-2016
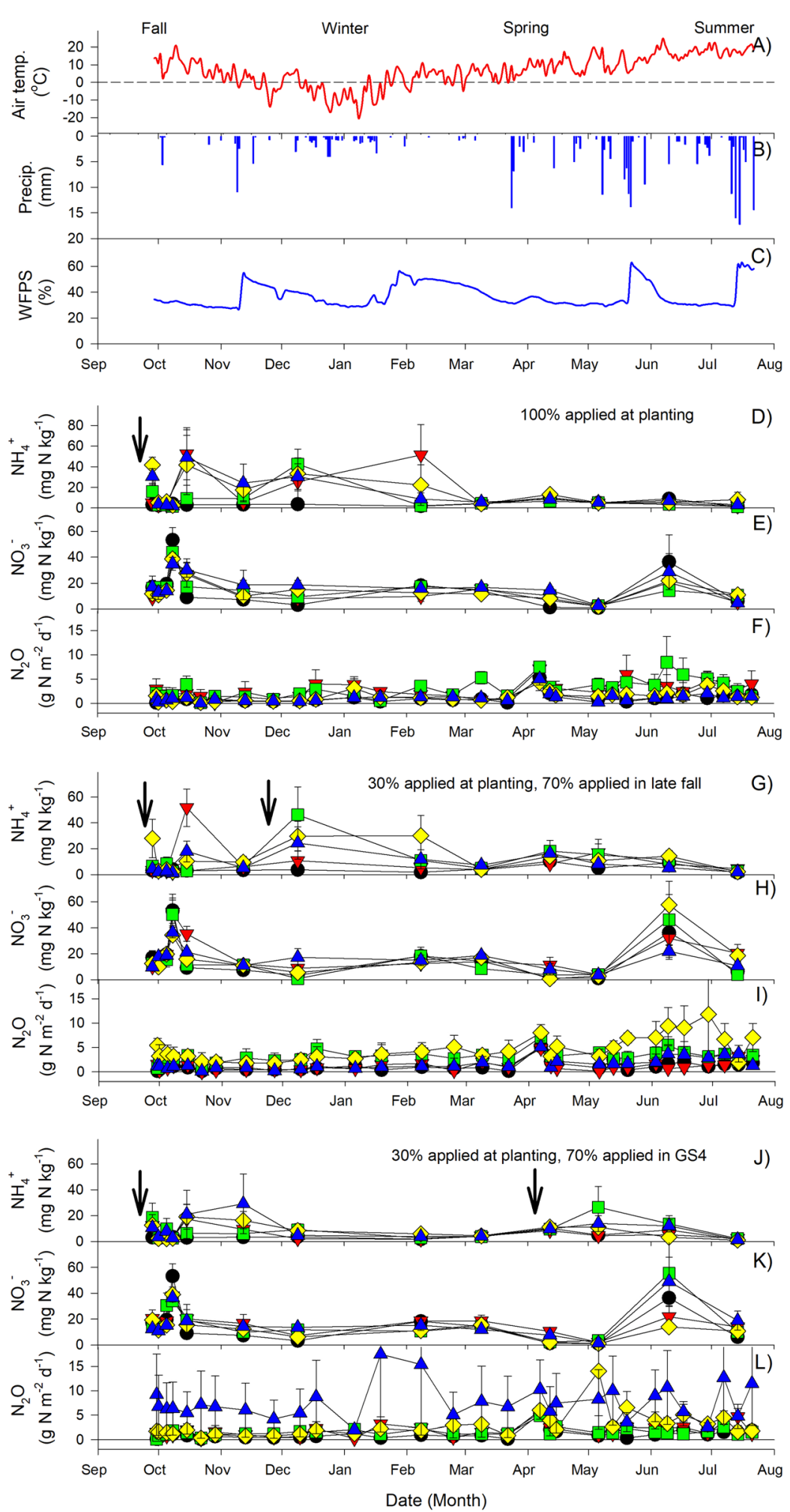
Fig. 3 a Air temperature, b precipitation (rain + snow), c waterfilled pore space at $50 \mathrm{~mm}$, and mean ( \pm the standard error of the mean) soil ammonium, soil nitrate and nitrous oxide fluxes for fluxes applied $100 \%$ at planting fertilizer $(\mathbf{d}-\mathbf{f})$, $30 \%$ applied at planting and $70 \%$ applied in late fall $\left(\mathbf{g}_{-}\right.$ i), and $30 \%$ applied at planting and $70 \%$ applied at Feekes growth stage $4(\mathbf{j}-$ l) for Year 3 (2016-2017). The black arrows represent the timing of fertilizer application
Year 3, 2016-2017
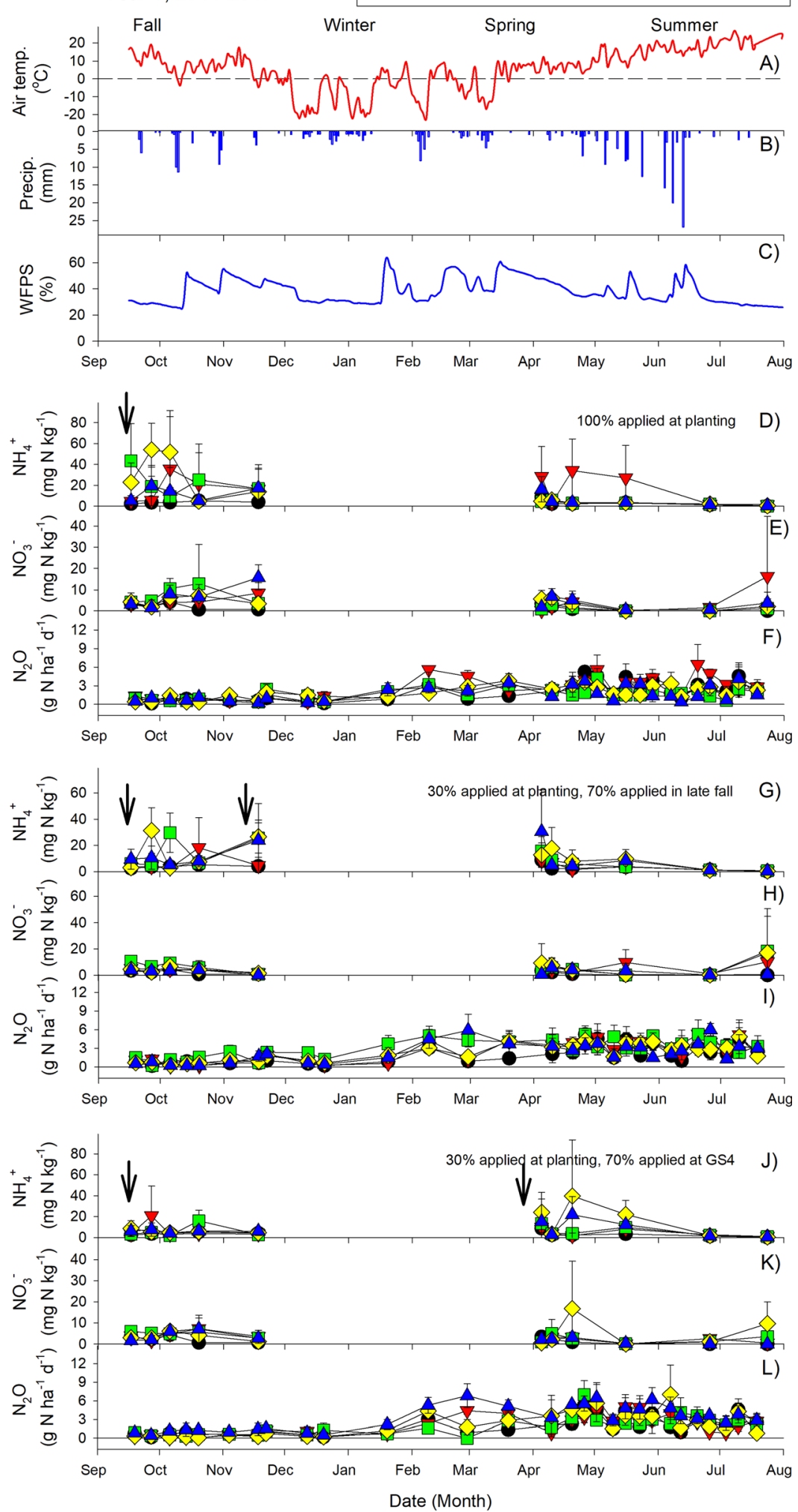
$7.46 \mathrm{~g} \mathrm{~N} \mathrm{ha}^{-1}$ day $^{-1}$, ranging from 2.01 to $17.51 \mathrm{~g} \mathrm{~N} \mathrm{ha}^{-1} \mathrm{day}^{-1}$ ) compared to all other fertilizer types and applications.

In Year 3, $\mathrm{N}_{2} \mathrm{O}$ fluxes did not increase after fertilizer application. Nitrous oxide fluxes were $\leq 2.49 \mathrm{~g} \mathrm{~N} \mathrm{ha}^{-1} \mathrm{day}^{-1}$ from all fertilizer types and applications before the winter (until November 30, 2016). Mean daily $\mathrm{N}_{2} \mathrm{O}$ fluxes in the winter, spring, and summer (between December 1, 2016, and July 19, 2017) reached a maximum of $7.03 \mathrm{~g} \mathrm{~N} \mathrm{ha}^{-1}$ day $^{-1}$. During this time period, average WFPS was low (39.3\%) with some instances of precipitation-induced increases (maximum $=60.9 \%$ ), and $\mathrm{NO}_{3}{ }^{-}$concentrations were low, averaging $3.71 \mathrm{mg} \mathrm{N} \mathrm{kg}^{-1}$ from all fertilized soils.

Segmented by application, $\mathrm{N}_{2} \mathrm{O}$ fluxes were positively correlated with $\mathrm{NO}_{3}{ }^{-}$and $\mathrm{NH}_{4}{ }^{+}$when fertilizer was split applied in late fall and GS4. When fertilizer was split applied in GS4, $\mathrm{N}_{2} \mathrm{O}$ fluxes were also negatively correlated with WFPS (Table 3 ). When grouped by fertilizer type, $\mathrm{N}_{2} \mathrm{O}$ fluxes were positively correlated with $\mathrm{NO}_{3}{ }^{-}$in Urea and $\mathrm{NI}+\mathrm{UI}$, and negatively correlated with $\mathrm{NO}_{3}{ }^{-}$in PCU. Nitrous oxide fluxes from NI and NI + UI were negatively correlated with WFPS, and $\mathrm{N}_{2} \mathrm{O}$ fluxes from NI + UI were positively correlated with air temperature. There were no consistent trends in correlation results when data was grouped by both fertilizer type and application regime (Table 3).

When grouped by Year, fertilizer type, or applications, the multiple regression models produced generally low $\mathrm{R}^{2}$ values ranging from 0 to 0.14 (Table 3 ). None of the environmental or soil variables were able to significantly predict $\mathrm{N}_{2} \mathrm{O}$ fluxes when $100 \%$ of the fertilizer was applied at planting (Table 3).

Cumulative nitrous oxide emissions and emissions factors

Cumulative $\mathrm{N}_{2} \mathrm{O}$ emissions from the controls (no $\mathrm{N}$ applied) were equivalent to $0.08 \mathrm{~kg} \mathrm{~N} \mathrm{ha}^{-1}$ ( \pm 0.03 standard error of the mean) in Year $1,0.32 \mathrm{~kg} \mathrm{~N}^{-1}$ $( \pm 0.03)$ in Year 2, and $0.50 \mathrm{~kg} \mathrm{~N} \mathrm{ha}^{-1}( \pm 0.10)$ in Year 3. When considering all fertilizer types and applications, cumulative $\mathrm{N}_{2} \mathrm{O}$ emissions from the fertilized treatments were significantly lower $(P$ $\leq 0.05$ ) in Year 1 (mean $=0.32 \mathrm{~kg} \mathrm{~N} \mathrm{ha}^{-1}$, ranging from 0.16 to $0.59 \mathrm{~kg} \mathrm{~N} \mathrm{ha}^{-1}$ ) than in Year 2 (mean $=0.63 \mathrm{~kg} \mathrm{~N} \mathrm{ha}^{-1}$, ranging from 0.32 to
$1.32 \mathrm{~kg} \mathrm{~N} \mathrm{ha}^{-1}$ ) or Year 3 (mean $=0.67 \mathrm{~kg} \mathrm{~N} \mathrm{ha}^{-1}$, ranging from 0.52 to $0.97 \mathrm{~kg} \mathrm{~N} \mathrm{ha}^{-1}$ ). In Years 1, 2, and 3 , an average equivalent of $0.133 \%, 0.215 \%$, and $0.093 \%$ of the $\mathrm{N}$ applied as fertilizer was emitted as $\mathrm{N}_{2} \mathrm{O}-\mathrm{N}$, respectively, and the emissions factors were significantly $(P \leq 0.05)$ lower in Year 3 than in Year 2.

Differences in fertilizer type did not cause differences in cumulative $\mathrm{N}_{2} \mathrm{O}$ emissions and emissions factors, but effects related to application were detected (Table 4). Fertilizer applied in late fall resulted in significantly higher cumulative $\mathrm{N}_{2} \mathrm{O}$ emissions and emissions factors compared to fertilizer applied at GS4 $(P \leq 0.10)$. However, neither split-application regime resulted in cumulative $\mathrm{N}_{2} \mathrm{O}$ emissions or emissions factors that differed from when $100 \%$ of the fertilizer was applied at planting.

There were significant interactions between Year and fertilizer type, and fertilizer type and application, for cumulative $\mathrm{N}_{2} \mathrm{O}$ emissions (Table 4). Cumulative $\mathrm{N}_{2} \mathrm{O}$ emissions were higher from $\mathrm{NI}$ and $\mathrm{UI}+\mathrm{NI}$ during Year 2 compared to NI and NI + UI during Year $1(P \leq 0.05$, Supplementary Table S1). The significant interaction effects for cumulative $\mathrm{N}_{2} \mathrm{O}$ emissions detected between fertilizer type and application were from higher $\mathrm{N}_{2} \mathrm{O}$ emissions from $\mathrm{NI}$ applied in late fall compared to NI applied at GS4 and Urea applied at planting (all $P \leq 0.10$ ).

\section{Discussion}

Fertilizer-induced $\mathrm{N}_{2} \mathrm{O}$ emissions were minimized by split application in spring but were not lowered by enhanced efficiency fertilizers

Coupling split fertilizer application and EEFs did not result in lower cumulative $\mathrm{N}_{2} \mathrm{O}$ emissions or emissions factors compared to applying $100 \%$ of the urea at planting. Enhanced efficiency fertilizers did not lessen cumulative $\mathrm{N}_{2} \mathrm{O}$ emissions or emissions factors compared to urea. Others have noted that EEFs, especially PCU and NI, can reduce $\mathrm{N}_{2} \mathrm{O}$ emissions compared to conventional fertilizers but they are more effective when soils are wet (Akiyama et al. 2010; Feng et al. 2016). Likely due to relatively dry soil conditions, we found no evidence that delays in $\mathrm{N}$ availability from EEFs compensated for ill-timed split fertilizer application thereby reducing $\mathrm{N}_{2} \mathrm{O}$ emissions. The only 


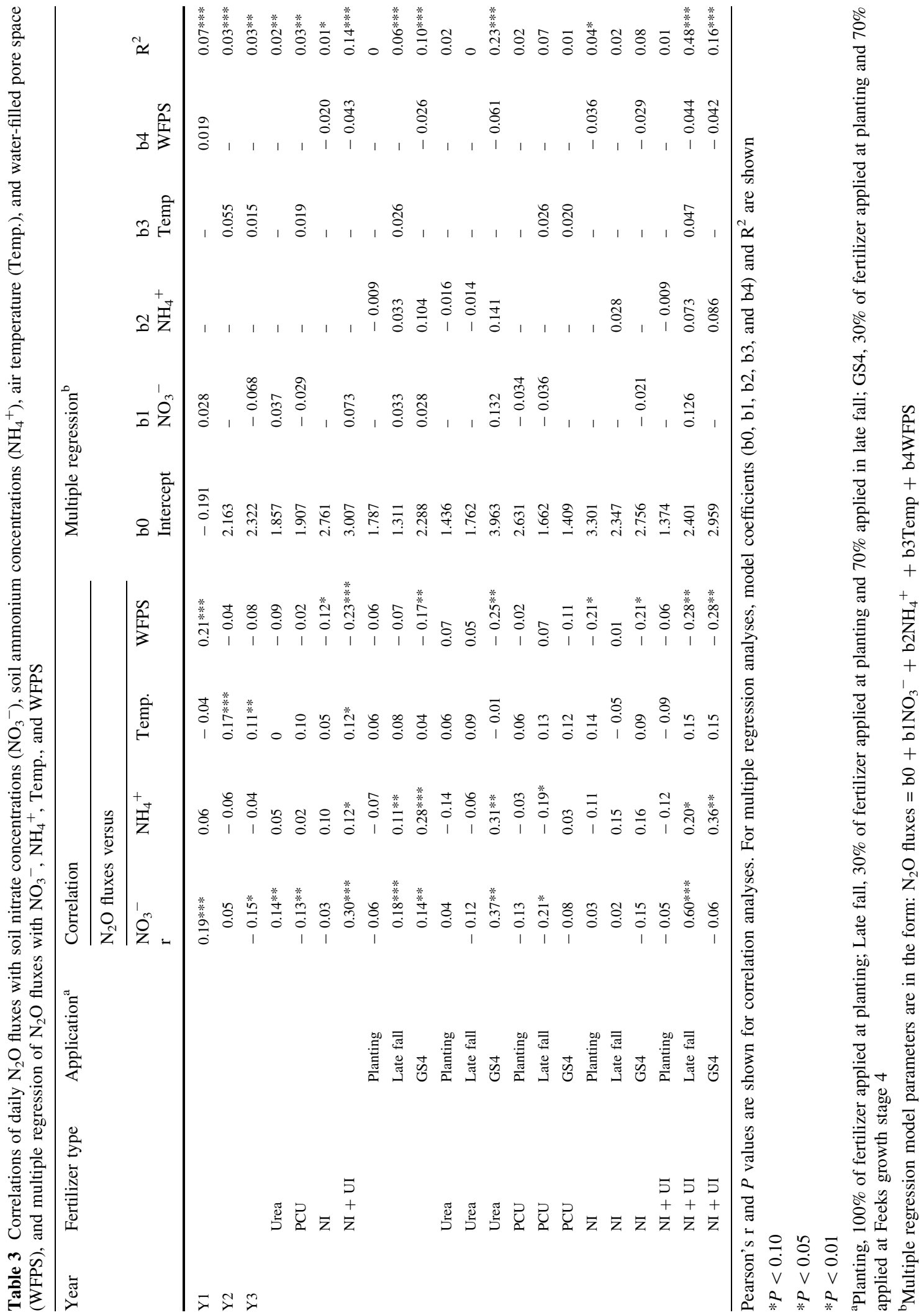


Table 4 Average ( \pm standard error of the mean) of the cumulative $\mathrm{N}_{2} \mathrm{O}$ emissions and emissions factors by each year, fertilizer type, and application

\begin{tabular}{|c|c|c|c|c|c|c|}
\hline Year & Fertilizer & \multicolumn{2}{|c|}{ Application regime } & \multicolumn{2}{|c|}{ Cumulative $\mathrm{N}_{2} \mathrm{O}\left(\mathrm{kg} \mathrm{N} \mathrm{ha}^{-1}\right)$} & Emissions factors $(\%)$ \\
\hline All & All & \multicolumn{2}{|c|}{$100 \%$ at planting } & \multicolumn{2}{|l|}{$0.53(0.05) \mathrm{ab}$} & $0.139(0.032) a b$ \\
\hline All & All & \multicolumn{2}{|c|}{$30 \%$ at planting and $70 \%$ at late fall } & \multicolumn{2}{|l|}{$0.65(0.07) \mathrm{b}$} & $0.213(0.044) b$ \\
\hline All & All & \multicolumn{2}{|c|}{$30 \%$ at planting and $70 \%$ at GS4 } & \multicolumn{2}{|l|}{$0.49(0.05) \mathrm{a}$} & $0.122(0.025) \mathrm{a}$ \\
\hline All & Urea & \multicolumn{2}{|l|}{ All } & \multicolumn{2}{|l|}{$0.51(0.05)$} & $0.121(0.022)$ \\
\hline All & PCU & \multicolumn{2}{|l|}{ All } & $0.54(0.06)$ & & $0.143(0.035)$ \\
\hline All & $\mathrm{NI}$ & \multicolumn{2}{|l|}{ All } & $0.59(0.07)$ & & $0.184(0.039)$ \\
\hline All & $\mathrm{NI}+\mathrm{UI}$ & \multicolumn{2}{|l|}{ All } & $0.59(0.09)$ & & $0.186(0.057)$ \\
\hline Year 1 & All & \multicolumn{2}{|l|}{ All } & $0.32(0.03) \mathrm{a}$ & & $0.133(0.018) \mathrm{ab}$ \\
\hline Year 2 & All & \multicolumn{2}{|l|}{ All } & $0.63(0.07) \mathrm{b}$ & & $0.215(0.050) \mathrm{b}$ \\
\hline Year 3 & All & \multicolumn{2}{|l|}{ All } & $0.67(0.03) \mathrm{b}$ & & $0.093(0.018) \mathrm{a}$ \\
\hline \multicolumn{2}{|c|}{ Source of variation } & df & SS & MS & F-statistic & $P$ values \\
\hline \multicolumn{7}{|c|}{ Cumulative $\mathrm{N}_{2} \mathrm{O}$} \\
\hline \multicolumn{2}{|c|}{ Application (A) } & 2 & 0.431 & 0.215 & 2.779 & 0.069 \\
\hline \multicolumn{2}{|c|}{ Fertilizer $(\mathrm{F})$} & 3 & 0.130 & 0.043 & 0.559 & 0.644 \\
\hline Year (Y) & & 2 & 2.696 & 1.348 & 17.397 & $<0.001$ \\
\hline $\mathrm{Y} \times \mathrm{F}$ & & 6 & 1.160 & 0.193 & 2.494 & 0.030 \\
\hline $\mathrm{Y} \times \mathrm{A}$ & & 4 & 0.207 & 0.052 & 0.669 & 0.615 \\
\hline $\mathrm{F} \times \mathrm{A}$ & & 6 & 1.433 & 0.239 & 3.083 & 0.009 \\
\hline $\mathrm{Y} \times \mathrm{F}$ & & 12 & 1.056 & 0.088 & 1.136 & 0.345 \\
\hline Residuc & & 71 & 5.501 & 0.077 & & \\
\hline Emissic & ictors & & & & & \\
\hline Applica & (A) & 2 & 0.165 & 0.083 & 2.448 & 0.094 \\
\hline Fertiliz & & 3 & 0.075 & 0.025 & 0.740 & 0.531 \\
\hline Year (Y & & 2 & 0.326 & 0.163 & 4.830 & 0.011 \\
\hline $\mathrm{Y} \times \mathrm{F}$ & & 6 & 0.510 & 0.085 & 2.519 & 0.288 \\
\hline $\mathrm{Y} \times \mathrm{A}$ & & 4 & 0.079 & 0.020 & 0.584 & 0.674 \\
\hline $\mathrm{F} \times \mathrm{A}$ & & 6 & 0.571 & 0.095 & 2.822 & 0.105 \\
\hline $\mathrm{Y} \times \mathrm{F}$ & & 12 & 0.479 & 0.040 & 1.184 & 0.309 \\
\hline Residuc & & 71 & 2.394 & 0.034 & & \\
\hline
\end{tabular}

ANOVA degrees of freedom (df), sum of squares (SS), mean sum of squares (MS), F-statistic and $P$ values are presented at the bottom of the table for main effects and interactions

Differences between groups for main effects are delineated with letters. Groups that do not share a letter are significantly different at $P \leq 0.10$

significant decreases in $\mathrm{N}_{2} \mathrm{O}$ emissions and emissions factors occurred when fertilizer was split applied at GS4 compared to split applied in late fall, but there were no significant differences in cumulative $\mathrm{N}_{2} \mathrm{O}$ emissions between single- and split-applications. The differences in the timing of split applied fertilizers can be attributed to differences in crop activity. In late fall, winter wheat growth slows. Rather than being used by the crop, fertilizer $\mathrm{N}$ applied in late fall was likely lost as $\mathrm{N}_{2} \mathrm{O}$ from denitrification over the winter (Malhi and Nyborg 1983), which can make substantial contributions to total $\mathrm{N}_{2} \mathrm{O}$ emissions (Wagner-Riddle et al. 2008). Nitrogen applied at GS4, which coincides with the greening up phase, was likely used by wheat for growth as this stage corresponds to increased plant $\mathrm{N}$ demand (Fowler et al. 1989; Alcoz et al. 1993; Rozas 
et al. 2004). Consistent with our results, others have similarly reported lower cumulative $\mathrm{N}_{2} \mathrm{O}$ emissions from wheat fertilized in the spring compared to the fall (Ellen and Spiertz 1980; Sowers et al. 1994; Burton et al. 2008).

\section{Environmental controls of $\mathrm{N}_{2} \mathrm{O}$ fluxes}

Nitrous oxide fluxes are known to exponentially increase when soil moisture increases beyond a threshold in the presence of warm temperatures and available N (Dobbie et al. 1999). Enhanced efficiency fertilizers or split fertilizer application can help reduce residual soil $\mathrm{N}$ after fertilization by matching $\mathrm{N}$ supply with plant $\mathrm{N}$ demand, and as a consequence, reduce soil $\mathrm{N}$ availability for $\mathrm{N}_{2} \mathrm{O}$ production. However, in a semiarid climate, soil moisture is a limiting factor for $\mathrm{N}_{2} \mathrm{O}$ production. Because of this, the timing of split application as it pertained to season and environmental conditions, rather than the fertilizer type, affected $\mathrm{N}_{2} \mathrm{O}$ emissions.

An assessment of the environmental controls on $\mathrm{N}_{2} \mathrm{O}$ fluxes failed to reveal strong relationships between $\mathrm{N}_{2} \mathrm{O}$ fluxes and the measured variables; $r$ values for the correlations and $\mathrm{R}^{2}$ values for the regression models were low. This was most notable when fertilizer was applied $100 \%$ at planting, and with the NI fertilizer treatment (Table 3). When all fertilizer was applied at planting, especially in soil that is generally dry but not so dry as to inhibit urea hydrolysis, substantial amounts of urea- $\mathrm{N}$ could have been lost as ammonia $\left(\mathrm{NH}_{3}\right)$ (Ferguson and Kissel 1986). Similar reports have been made regarding NI, which can enhance $\mathrm{NH}_{3}$ losses following fertilizer application by extending the amount of time $\mathrm{N}$ remains in soil as $\mathrm{NH}_{4}{ }^{+}$(Soares et al. 2012; Recio et al. 2018). These potential losses of $\mathrm{N}$ through unmeasured pathways may be hampering our ability to characterize the controls of $\mathrm{N}_{2} \mathrm{O}$ fluxes in these treatments.

Urea and $\mathrm{NI}+\mathrm{UI}$, and the split application regimes, showed positive relationships between $\mathrm{N}_{2} \mathrm{O}$ fluxes, and $\mathrm{NO}_{3}{ }^{-}$and $\mathrm{NH}_{4}{ }^{+}$. This can be attributed to enhanced variation in $\mathrm{N}_{2} \mathrm{O}$ fluxes and soil $\mathrm{N}$ concentrations after fertilizer application, and in the spring and summer when crops were active, and warm temperatures and intermediate-level WFPS could support mineralization and nitrification (Addiscott 1983; Stark 1996). Different relationships were observed with PCU, which was negatively related to
$\mathrm{NO}_{3}{ }^{-}$but positively related to temperature. Temperature is a strong predictor of urea release from PCU (Golden et al. 2011). The negative relationship between $\mathrm{N}_{2} \mathrm{O}$ fluxes and $\mathrm{NO}_{3}{ }^{-}$in the PCU treatment suggests the delay in $\mathrm{N}$ release caused subsequent $\mathrm{N}$ transformations in soil and $\mathrm{NO}_{3}{ }^{-}$availability to misalign with conditions that were permissible for $\mathrm{N}_{2} \mathrm{O}$ production.

The negative relationships often observed between $\mathrm{N}_{2} \mathrm{O}$ fluxes and WFPS are likely an artifact of the relationships between WFPS and temperature inherent of a semiarid climate; when soil was wetter and more favorable for high $\mathrm{N}_{2} \mathrm{O}$ production, temperatures were low which limited microbial activity (Holtan-Hartwig et al. 2002).

The WFPS values measured during our study ranged from 25 to $67 \%$ over all three years. This is lower than considered optimal for denitrificationinduced $\mathrm{N}_{2} \mathrm{O}$ fluxes (Linn and Doran 1984; Abbasi and Adams 2000; Müller and Sherlock 2004). However, denitrification and nitrifier-denitrification can make significant contributions to total $\mathrm{N}_{2} \mathrm{O}$ production in soils fertilized with urea under aerobic conditions (Venterea et al. 2015). Others have reported that nitrification can be the primary pathway for $\mathrm{N}_{2} \mathrm{O}$ production in semiarid soils (Aguilera et al. 2013). However, relatively lower $\mathrm{N}_{2} \mathrm{O}$ emissions are expected from aerobic biological pathways (Zhu et al. 2013). Low soil moisture explains why any increases in $\mathrm{N}_{2} \mathrm{O}$ fluxes immediately after fertilizer application were not disproportionately high compared to other times (Van der Weerden et al. 2016; Awale and Chatterjee 2017) as fertilizer-induced $\mathrm{N}_{2} \mathrm{O}$ fluxes can be muted by dry soil conditions (Barton et al. 2008).

It should be noted that our soil sampling schedule likely impacted our interpretation of the $\mathrm{N}_{2} \mathrm{O}$ fluxes and soil $\mathrm{N}$ variability. More frequent measurements of $\mathrm{N}_{2} \mathrm{O}$ fluxes and soil $\mathrm{N}$ concentrations occurred after planting than at other times. It is likely that we missed some variations in these factors after the late fall or GS4 application, or during the winter when our measurements were less frequent.

Cumulative emissions and emissions factors were low for fertilized soil

The North American Great Plains are characterized by unpredictable precipitation and high 
evapotranspiration, and this leads to low soil moisture and therefore low $\mathrm{N}_{2} \mathrm{O}$ emissions (Padbury et al. 2002; Rochette et al. 2008). Our cumulative $\mathrm{N}_{2} \mathrm{O}$ emissions from fertilized soils ( 0.16 to $1.32 \mathrm{~kg} \mathrm{~N} \mathrm{ha}^{-1}$ ) were within range of those reported from studies conducted nearby. From the Parkland Region of Alberta, Canada, $\mathrm{N}_{2} \mathrm{O}$ emissions from dryland wheat fertilized with urea were up to $2.02 \mathrm{~kg} \mathrm{~N} \mathrm{ha}^{-1}$ (Lemke et al. 1999). Nitrous oxide emissions from wheat rotations in Bozeman, Montana, USA, ranged from 0.10 to $0.65 \mathrm{~kg} \mathrm{~N}_{2} \mathrm{O}-\mathrm{N} \mathrm{ha}^{-1}$ year $^{-1}$ (Dusenbury et al. 2008).

Our emissions factors ranged from 0.009 and $0.688 \%$ of the $\mathrm{N}$ applied, which is within the range of the disaggregated IPCC emissions factors of between 0.0 and $1.1 \%$ for dry climates (Hergoualc'h et al. 2019). A majority of our emissions factors were $<0.20 \%$, which is consistent with an estimate of $0.16 \%$ created using the IPCC Tier II methodology for Brown and Dark Brown soils on the Canadian Prairies (Rochette et al. 2008). Most of the highest emissions factors measured during our study occurred in Year 2 and when aggregated by application, the highest values occurred with the late fall split application. The impacts of split fertilizer application have not been previously considered as a part of a regional emissions factor for the Canadian Prairies, but our results suggest that for dryland, over winter crops, such an evaluation may have some merit.

Emissions factors were highest in Year 2 and lowest in Year 3, which was inconsistent with the yearly variation in cumulative $\mathrm{N}_{2} \mathrm{O}$ emissions. This discrepancy suggests fertilizer $\mathrm{N}$ was not used as efficiently in Year 2 compared to Year 3, however, we did not measure yield factors so this was not addressed in this study. While the fertilizer application rates were similar between years, the phenological requirements for $\mathrm{N}$ (and therefore plant $\mathrm{N}$ uptake) will vary based on wheat health, which will be affected by factors like temperature and precipitation (Fowler et al. 1989). Our fertilizer rates were not excessive for the system as crop $\mathrm{N}$ requirements were estimated by the PRS probes prior to fertilizer application (Hangs et al. 2002) and we only applied at $80 \%$ of the recommended rates. It is likely that a combination of plant dynamics and climate variability affected yearly emissions factors.
Implications for fertilizer best management practices in dryland winter wheat crops

Ideally, best management practices for fertilizer will minimize $\mathrm{N}_{2} \mathrm{O}$ emissions. We found that EEFs did not mitigate $\mathrm{N}_{2} \mathrm{O}$ emissions compared to Urea. The semiarid climate conditions in our study area are typical of the Northern Great Plains where wheat crops are commonly cultivated. Enhanced efficiency fertilizer use in this location may be a more suitable fertilizer option for irrigated fields where water inputs can be regulated, or for spring crops, where soil is likely to be wetter and more permissible to high $\mathrm{N}_{2} \mathrm{O}$ fluxes.

For mitigating $\mathrm{N}_{2} \mathrm{O}$ emissions using split application, the timing of the application is important. Split applying all fertilizer before the winter can amplify cumulative $\mathrm{N}_{2} \mathrm{O}$ emissions and emissions factors. However, split application requires additional labor and fuel costs and there is additional risk that climate or soil conditions could prevent driving on the fields at a time ideal for the second application. When selecting a fertilization strategy, most producers would evaluate the gains in yield and factors like protein (not measured in this study) along with the logistics of split application, but considerations of $\mathrm{N}_{2} \mathrm{O}$ emissions are more difficult for them to estimate. Our study showed that applying $100 \%$ of the fertilizer at planting did not result in significantly different $\mathrm{N}_{2} \mathrm{O}$ emissions or emissions factors compared to split application at GS4. However, if split application leads to greater yield and protein, a split application at GS4 may be a worthwhile risk and provide an added benefit of slightly reduced average $\mathrm{N}_{2} \mathrm{O}$ emissions in dryland winter crops.

\section{Conclusions}

For dryland winter wheat crops, split application with a majority of fertilizer being applied in the spring at the greening up stage of the crop cycle showed the greatest potential to minimize $\mathrm{N}_{2} \mathrm{O}$ emissions. As fertilizer management decisions are not made solely on $\mathrm{N}_{2} \mathrm{O}$ emissions, future research should also incorporate $\mathrm{N}$ concentrations in crop yields as this would provide a more complete evaluation of the fate of $\mathrm{N}$ fertilizer. If wheat grain $\mathrm{N}$ concentrations are greater when fertilizer is split applied at planting and GS4, and $\mathrm{N}_{2} \mathrm{O}$ emissions are minimized, then the enhanced risk 
associated with split application may be outweighed by the combined agronomic returns and environmental benefits.

Acknowledgements We gratefully acknowledge the scholarship provided to the lead author by China Scholarship Council Ministry of Education, P. R. China, and Lethbridge Research and Development Centre. Thank you to Key Laboratory of Grassland Resources, Ministry of Education P.R. of China. Funding for this research was provided by Agriculture and Agri-Food Canada, Ducks Unlimited Canada, Alberta Wheat Commission, Winter Cereals Manitoba Inc., Saskatchewan Winter Cereals Development Commission, Dow AgroServices, Koch Agronomic Services, and Western Ag Innovations. Thank you to Courtney Soden, Kui Liu, James Elwood, and Elisha Jones for their technical assistance.

Open Access This article is licensed under a Creative Commons Attribution 4.0 International License, which permits use, sharing, adaptation, distribution and reproduction in any medium or format, as long as you give appropriate credit to the original author(s) and the source, provide a link to the Creative Commons licence, and indicate if changes were made. The images or other third party material in this article are included in the article's Creative Commons licence, unless indicated otherwise in a credit line to the material. If material is not included in the article's Creative Commons licence and your intended use is not permitted by statutory regulation or exceeds the permitted use, you will need to obtain permission directly from the copyright holder. To view a copy of this licence, visit http://creativecommons.org/licenses/by/4.0/.

\section{References}

Abbasi MK, Adams WA (2000) Gaseous N emission during simultaneous nitrification-denitrification associated with mineral $\mathrm{N}$ fertilization to a grassland soil under field conditions. Soil Biol Biochem 32:1251-1259

Addiscott T (1983) Kinetics and temperature relationships of mineralization and nitrification in Rothamsted soils with differing histories. J Soil Sci 34:343-353

Aguilera E, Lassaletta L, Sanz-Cobena A, Garnier J, Vallejo A (2013) The potential of organic fertilizers and water management to reduce $\mathrm{N}_{2} \mathrm{O}$ emissions in Mediterranean climate cropping systems. A review. Agric Ecosyst Environ 164:32-52

Akiyama H, Yan X, Yagi K (2010) Evaluation of effectiveness of enhanced-efficiency fertilizers as mitigation options for $\mathrm{N}_{2} \mathrm{O}$ and $\mathrm{NO}$ emissions from agricultural soils: metaanalysis. Glob Change Biol 16:1837-1846

Alcoz MM, Hons FM, Haby VA (1993) Nitrogen fertilization timing effect on wheat production, nitrogen uptake efficiency, and residual soil nitrogen. Agron J 85:1198-1203
Austin AT, Yahdjian L, Stark JM, Belnap J, Porporato A, Norton U, Ravetta DA, Schaeffer SM (2004) Water pulses and biogeochemical cycles in arid and semiarid ecosystems. Oecologia 141:221-235

Awale R, Chatterjee A (2017) Enhanced efficiency nitrogen products influence ammonia volatilization and nitrous oxide emission from two contrasting soils. Agron J 109:47-57

Barton L, Kiese R, Gatter D, Butterbach-bahl K, Buck R, Hinz C, Murphy DV (2008) Nitrous oxide emissions from a cropped soil in a semi-arid climate. Glob Change Biol 14:177-192

Black A, Sherlock R, Cameron K, Smith N, Goh K (1985) Comparison of three field methods for measuring ammonia volatilization from urea granules broadcast on to pasture. J Soil Sci 36:271-280

Black A, Sherlock R, Smith N (1987) Effect of timing of simulated rainfall on ammonia volatilization from urea, applied to soil of varying moisture content. J Soil Sci 38:679-687

Burton D, Li X, Grant C (2008) Influence of fertilizer nitrogen source and management practice on $\mathrm{N}_{2} \mathrm{O}$ emissions from two black chernozemic soils. Can J Soil Sci 88:219-227

Chang C, Janzen H, Cho C (1998) Nitrous oxide emission from long-term manured soils. Soil Sci Soc Am J 62:677-682

Dobbie K, McTaggart I, Smith K (1999) Nitrous oxide emissions from intensive agricultural systems: variations between crops and seasons, key driving variables, and mean emission factors. J Geophys Res Atmos 104:26891-26899

Dusenbury M, Engel R, Miller P, Lemke R, Wallander R (2008) Nitrous oxide emissions from a northern great plains soil as influenced by nitrogen management and cropping systems. J Environ Qual 37:542-550

Ellen J, Spiertz J (1980) Effects of rate and timing of nitrogen dressings on grain yield formation of winter wheat $(T$. aestivum L.). Fertil Res 1:177-190

Feng J, Li F, Deng A, Feng X, Fang F, Zhang W (2016) Integrated assessment of the impact of enhanced-efficiency nitrogen fertilizer on $\mathrm{N}_{2} \mathrm{O}$ emission and crop yield. Agric Ecosyst Environ 231:218-228

Ferguson R, Kissel D (1986) Effects of soil drying on ammonia volatilization from surface-applied urea. Soil Sci Soc Am J 50:485-490

Fowler D, Brydon J, Baker R (1989) Nitrogen fertilization of notill winter wheat and rye. I. Yield agronomic responses. Agron J 81:66-72

Golden B, Slaton N, Norman R, Gbur E, Wilson C (2011) Nitrogen release from environmentally smart nitrogen fertilizer as influenced by soil series, temperature, moisture, and incubation method. Commun Soil Sci Plant Anal 42:1809-1824

Gregorich E, Rochette P, VandenBygaart A, Angers D (2005) Greenhouse gas contributions of agricultural soils and potential mitigation practices in Eastern Canada. Soil Till Res 83:53-72

Hangs R, Greer K, Sulewski C, Hicks D (2002) Plant root simulator ${ }^{\mathrm{TM}}$-probes: an effective alternative for routine soil testing. In: Soil and crops workshop proceedings. University of Saskatchewan 
Hergoualc'h K, Akiyama H, Bernoux M, Chirinda N, Del Prado A, Kasimir Ä, MacDonald D, Ogle SM, Regina K, van der Weerden T (2019) 2019 Refinement to the 2006 IPCC guidelines for national greenhouse gas inventories: agriculture forestry and other land use, p 11

Holtan-Hartwig L, Dörsch P, Bakken L (2002) Low temperature control of soil denitrifying communities: kinetics of $\mathrm{N}_{2} \mathrm{O}$ production and reduction. Soil Biol Biochem 34:1797-1806

Keeney DR, Nelson D (1982) Nitrogen-inorganic forms. In: Page AL (ed) Methods of soil analysis. Part 2. Chemical and microbiological properties. American Society of Agronomy, Soil Science Society of America, Madison, pp 643-698

Kutner M, Nachtsheim C, Neter J (2004) Applied linear regression models, 4th edn. McGraw-Hill, New York

Large EC (1954) Growth stages in cereals illustration of the Feekes scale. Plant Pathol 3:128-129

Lemke R, Izaurralde R, Nyborg M, Solberg E (1999) Tillage and $\mathrm{N}$ source influence soil-emitted nitrous oxide in the Alberta Parkland region. Can J Soil Sci 79:15-24

Linn DM, Doran JW (1984) Effect of water-filled pore space on carbon dioxide and nitrous oxide production in tilled and nontilled soils. Soil Sci Soc Am J 48:1267-1272

Mahler RL, Koehler FE, Lutcher L (1994) Nitrogen source, timing of application, and placement: effects on winter wheat production. Agron J 86:637-642

Malhi S, Nyborg M (1983) Field study of the fate of fall-applied $15 \mathrm{~N}$-labelled fertilizers in three alberta soils 1 . Agron $\mathrm{J}$ 75:71-74

Müller C, Sherlock RR (2004) Nitrous oxide emissions from temperate grassland ecosystems in the Northern and Southern Hemispheres. Glob Biogeochem Cycles 18:GB1045-1

Padbury G, Waltman S, Caprio J, Coen G, McGinn S, Mortensen D, Nielsen G, Sinclair R (2002) Agroecosystems and land resources of the northern Great Plains. Agron J 94:251-261

Parkin T, Venterea R, Hargreaves S (2012) Calculating the detection limits of chamber-based soil greenhouse gas flux measurements. J Environ Qual 41:705-715

Raun WR, Johnson GV (1999) Improving nitrogen use efficiency for cereal production. Agron J 91:357-363

Recio J, Vallejo A, Le-Noe J, Garnier J, García-Marco S, Álvarez JM, Sanz-Cobena A (2018) The effect of nitrification inhibitors on $\mathrm{NH}_{3}$ and $\mathrm{N}_{2} \mathrm{O}$ emissions in highly $\mathrm{N}$ fertilized irrigated Mediterranean cropping systems. Sci Total Environ 636:427-436

Rochette P, Worth DE, Lemke RL, McConkey BG, Pennock DJ, Wagner-Riddle C, Desjardins R (2008) Estimation of $\mathrm{N}_{2} \mathrm{O}$ emissions from agricultural soils in Canada. I. Development of a country-specific methodology. Can J Soil Sci 88:641-654
Rozas HRS, Echeverría HE, Barbieri PA (2004) Nitrogen balance as affected by application time and nitrogen fertilizer rate in irrigated no-tillage maize. Agron J 96:1622-1631

Sims G, Ellsworth T, Mulvaney R (1995) Microscale determination of inorganic nitrogen in water and soil extracts. Commun Soil Sci Plant Anal 26:303-316

Soares JR, Cantarella H, de Campos Menegale ML (2012) Ammonia volatilization losses from surface-applied urea with urease and nitrification inhibitors. Soil Biol Biochem 52:82-89

Soil Classification Working Group (1998) The Canadian system of soil classification. NRC Research Press, Ottawa

Sowers KE, Miller BC, Pan WL (1994) Optimizing yield and grain protein in soft white winter wheat with split nitrogen applications. Agron J 86:1020-1025

Stark JM (1996) Modeling the temperature response of nitrification. Biogeochemistry 35:433-445

Sturm M, Taras B, Liston GE, Derksen C, Jonas T, Lea J (2010) Estimating snow water equivalent using snow depth data and climate classes. J Hydrometeorol 11:1380-1394

Trenkel ME (2010) Slow-and controlled-release and stabilized fertilizers: an option for enhancing nutrient use efficiency in agriculture. IFA, International Fertilizer Industry Association, Paris

Van der Weerden TJ, Luo J, Di HJ, Podolyan A, Phillips RL, Saggar S, de Klein CAM, Cox N, Ettema P, Rys G (2016) Nitrous oxide emissions from urea fertiliser and effluent with and without inhibitors applied to pasture. Agric Ecosyst Environ 219:58-70

Venterea R, Parkin T, Cardebas L, Petersen S, Petersen A (2012) Data analysis considerations. In: De Klein C, Harvey M (eds) Nitrous oxide chamber methodology guidelines. Global research alliance on agricultural greenhouse gases. Ministry for Primary Industries, Wellington, pp 95-121

Venterea RT, Clough TJ, Coulter JA, Breuillin-Sessoms F, Wang P, Sadowsky MJ (2015) Ammonium sorption and ammonia inhibition of nitrite-oxidizing bacteria explain contrasting soil $\mathrm{N}_{2} \mathrm{O}$ production. Sci Rep 5:12153

Wagner-Riddle C, Hu Q, Van Bochove E, Jayasundara S (2008) Linking nitrous oxide flux during spring thaw to nitrate denitrification in the soil profile. Soil Sci Soc Am J 72:908-916

Zhu X, Burger M, Doane TA, Horwath WR (2013) Ammonia oxidation pathways and nitrifier denitrification are significant sources of $\mathrm{N}_{2} \mathrm{O}$ and $\mathrm{NO}$ under low oxygen availability. Proc Natl Acad Sci 110:6328-6333

Publisher's Note Springer Nature remains neutral with regard to jurisdictional claims in published maps and institutional affiliations. 